NEW LITERARIA-

An International Journal of Interdisciplinary Studies in Humanities

Volume 2, No. 2, July- August, 2021, PP. 24-32

ISSN: 2582-7375

DOI: https://dx.doi.org/10.48189/nl.2021.v02i2.004

www.newliteraria.com

\title{
Pandemic; A Political Satire: Re-Surfacing the Dysfuctional Government Through the Works of Stephen King and Robin Cook
}

\author{
Sanghamitra Ghatak
}

\begin{abstract}
Pandemic came as a ubiquitous threat to the entire world. This calls for a situation which can be combated by a huge dependency on the governmental system. But the problem arises when it is the same government which takes recourse to oppression and start tyrannizing its own subject. The global pandemic that had struck us two years back has now become a part of our life. But what was seen most evident during this period of tremendous crisis is the total failure of the governmental system in safeguarding the lives of their very own people. It brought out the persistent fractures already prevalent in the society. The systematic approach to brainwash the mass against the viruses, their nature, effects on human body and safeguarding the interest of a selected few by hindering the correct investigation about the origin of the virus exposes the authority that rules over the people. Almost all the governments have faltered in the respect of correct security to their people. However, it is surprising to note that, the very reflection of these dysfunctional services found it's reflect in the world of literature and entertainment as well. A close analysis of the works like Robin Cook's Outbreak and Contagion and Stephen King's The Mist and The Stand will bring forth this same problem of a demolishing government in midst of pandemic affected situations. These pandemic literatures not just focus on the crisis at hand and how to deal with it, but also sheds light on the reasons of their occurrences at the first place. Mostly being a governmental project going wrong, and the ensuing negligence on the part of such authorities to bring on the final doomsday.
\end{abstract}

Keywords: Governmental Oppression, Data Manipulation, Anti-democracy, Mutation, Vaccine Dilemma.

\section{Introduction}

Pandemics and diseases are not rare occurrences at the face of Earth. Over the centuries, mankind had repeatedly been the victims of different kind of plague and virus outbreaks. Yet, each time we faced such a situation it seemed magnified in outstanding propensities and the proportion seemed to be quite out of hand. This can either be due to lack of medical facilities, or ignorance at the part of a strong vigilant government to tackle a situation that may arise abruptly. The outbreak of Covid-19 not just provided us with a repetition of history, it laid bare the fractured properties of the society that was so far garbed under the shadows of false data and high sounding speeches. Undoubtedly the medical proceedings functioning currently are not adequately progressed to tackle the situation at hand. But a far greater sham that has been brought out due to this is the political incompetence. Covid-19 has been anti-democratic in its approach to say the least.

Over the course of time the issues of apocalypse have been dealt with in various forms of art. It is an intriguing factor to observe how much of these fictionalized scenarios paved its 
way into reality at the wake of a pandemic the world is suffering through today. An introspection into the works of Robin Cook and Stephen King thus become very important dealing with realities of both medical fields and the government oppression which denounces the general public to provide assistance to battle against their right to very existence. Stephen King made one of his character from The Stand quote the lines of 'The Second Coming' by W.B Yeats, "Things fall apart; the centre cannot hold" to indicate the ruptured state of governance the situation has went to fulfill the selfish motives of Governmental projects.

\section{General Approach of the Authorities}

It is understandable as a fact that the outbreak may sometimes come out on a grim pretext without the prior expectations of any organization; be it that of the medical researchers or the government inducing those research bodies. Despite keeping this fact in mind, the approaches of the executive body can be found out rightly ignorant in most cases. This can come out as an attempt to safeguard one's own interest at the cost of risking the lives of others. Invariantly these led to the situations expounding to a limit of beyond recovery. The ignorance, sheer denial and underplaying the situation at hand constructs the preliminary behavioural approaches, which should be nothing but vigilant in nature.

\subsection{Hiding of Data}

In order to maintain the facade of a stabilized situation it becomes increasingly important for the authorities to retain the mask of normalcy. These lead them to hide and sometimes rupturing of data which could have otherwise provided us with a clear picture about the real state of being. As a means to suppress the proper information the governments employ deliberate obfuscation of internet information. As we find in the case of China, when at the early stage of the virus manifestation the official data as well as the indication of the first case was kept blurred from the rest of the world. In a recent publication, the BBC (2021) pointed out that China refused to provide data to WHO team with reference to Professor Dwyer's interview to Reuters. Here, Australian based Microbiologist, Professor Dominic Dwyer made it clear that the WHO team on requesting raw patient data from earlier cases had received only but a summary from the Government's end. This shadowing of data and facts resembles in its literary counterpart, when in King's fictionalized work The Mist, till the very end of the novella we are unaware of the actuality of the project undertaken by the nearby military base. The project was kept under such a secret that even the cadets involved with the base were kept away from the actual information. The mist and the deadly animals coming out as a result of a failure of the project called 'Project Arrowhead' were self-explanatory of the necessity of the government to maintain this code of privacy from the general public to continue with their researches without protests.

People resorting to official data to make sense of their given situation were rendered helpless in absence of any concrete information available on different platforms. The cases and data regarding the death rates were distorted which can be reasoned out through two prevalent factors, one being the poor collection practice, the government itself was instrumental in the obstruction of the data; the second being regional differences, which was noticeable in the case of Italy. The difference in various regions also meant a change in the socio-economic factors which are to be distinguished clearly in order to collect data and provide proper facility. As we can find a sudden spike in the number of cases and death rates in West Bengal in comparison to the rest of the country, just after the rallies and processions of the general election took place. . An exponential rise of infection by 75 times was noticed due to mass gathering during the rallies as recorded by Hindustan Times (Thakur, 2021). Apart from this a major discrepancy that was faced was a huge margin that persisted between the official data and that which was the ground reality. It was almost impossible to capture the real-time developments happenings 
Pandemic; A Political Satire: Re-Surfacing the Dysfuctional Government Through the Works of Stephen King and Robin Cook

on ground zero.

\subsection{Denial of a Virus}

Denial of any unusual activity comes out as a natural consequence to hide the situation at hand. This is presented to us as an intension to prevent unleashing any panic among the citizens. In King's post-apocalyptic novel, The Stand we find the President of America declare that it is nothing but a 'common flu' despite being in full knowledge about the viral biological weapon that was being monitored within the U.S. Department of Defense Laboratory which had the power to annihilate a significant portion of world's population. This ignorance on the part of the government and failure to take informative actions led to the crisis where the entire populace comes under the garb of the virus ultimately leading to the wiping up of civilization.

It is shocking when we find out the similar action grounds being adopted by the Government and the other higher authorities. Somewhere a clear distinction between literature and reality seems to be obliterating. The New York Times in their $25^{\text {th }}$ September issue of 1994 raised a concern about an outbreak of what seemed to be a pneumonia plague in the regions of Surat. But in absence of any potential concern from any authoritative sectors nearly 300,000 people departed from the city. As a consequent effect the virus spread its way to the entire Nation reporting a total of 5000 suspected cases with 53 deaths around the country. This denial from the then Chief Minister of Gujrat claiming in a press conference about the nature of outbreak to be nothing more than usual pneumonia was considered to be the cause of confusion among the citizens against taking precautionary measures.

On recent occurrences regarding the Covid-19 situation we found that the Ex-President of America leading out speeches to regard the virus noting more than a flu, when he said, "Wash your hands, stay clean. You don't have to necessarily grab every handrail" (Rogers, 2020). It was later when in interviews he made the confession about the real propensity of the virus and that it is airborne and deadlier than anything else. This was regarded by him as a precautionary measure so as not to inflict panic among his people, unable to comprehend that it in fact lead to uncertainty among the masses about the seriousness of the situation at hand.

\subsubsection{Underplaying the Graveness of the Situation}

Incapacity to maintain the protocols during the emergency period brought out the sloppy handling of the pandemic, this in fact exaggerated the situation which could otherwise be brought under control. The Stand undergoes an event when the Government unknowingly leads the release of the virus in USSR, its satellite countries and China resulting in a mass evacuation of the world population. It baffles us when in midst of the crisis situation reports of the Malaysian authorities allowing a religious gathering surfaced the news. Millions of devotees gathered around in Haridwar to participate in Kumbh Mela festival even when India was battling the second wave of the coronavirus. From the very beginning of the outbreak we found a misleading conspiracy against the usage of masks. False data of masks lowering the oxygen level in the body and other baseless concepts emerged in the social forum. What is even more alarming is when the leaders and the President of the country themselves undermine public health guidance against wearing masks. It becomes more and more difficult for the common folk to fight this situation when the cynical pundits and the authorities do not pay much repercussion for spreading the wrong consciousness among the masses. Similar instance is projected in The Mist, where the sole government official stuck in the middle of the crisis within the retail store; it was this same person living oblivious to the situation at hand. His resistance to accept anything cryptic leading to the mist ultimately resulted in a fair share of death counts from among the people stuck within the store.

\subsection{Recruitment of the Affected Citizens}


With the onset of the spreading of the viruses it becomes very important to identify the victims and segregate them away from the general public. This is a process that becomes increasingly difficult especially for countries with greater population. In course of time when it becomes difficult to track the exact line of spreading, locating of the victims on the part of government is unattainable. At this juncture we find instances from among different literary sources coming out with different techniques to recruit the victims. For instance, in Robin Cook's Outbreak, we find the U.S.A. government requesting the victims to cooperate along with them by drawing white curtains on their main entrances so the army can locate the houses of the affected ones. It is an uncanny resemblance that we find when the Government of India generated an app where the citizens were asked to earnestly put in the data of their present condition so as to get a clear picture about their status of being. In the later stage when testing became more rampant, a positive report was directly conveyed to the local municipality who would undertake the course of action thereafter of providing an ambulance or any other help if ever required.

It is both surprising and shocking to undergo the portion from The Stand where it is seen a hunt down of all those people who came in contact with the security guard of the Department of Defense Laboratory, Charles Campion. He was regarded as the one responsible for spreading the virus as he escaped the lab right after the accidental release of the virus. This fictionalized proposition might seem exaggerated when it first came out. But the resemblance cannot be denied when the world was shocked with the news of North-Korea issuing shoot-tokill orders to prevent the coronavirus (AFP, 2020).

\section{Safeguarding the Authoritative Interest}

It is now a known fact that a huge number of data was both hidden and manipulated about the reason and knowhow of the virus. The presumable epicenter of the virus being regarded as the Wuhan market of China led the Chinese Government to take all precautionary measures to safeguard their interests. Apart from these we see a necessitated delay on the part of World Health Organization on issuing the guidelines and a proper check about the true nature of the virus. This so raged the other nations, that we can find the corona virus being called out as the 'China Virus' in press conferences many a times (Chiu, 2020).

\subsection{Identity of the Source Remains Obscure}

Despite lots of speculation about the origin or, the actual source of the outbreak of a pandemic of this scale, no clear data has been procured regarding its source. As a consequent result this has led to a number of conspiracy theories. But no concrete evidence on any can be found in order to zero down on one particular path of investigation. In the 2007 adaptation of The Mist we find the town of Bridgton comes under the garb of a mist of unprecedented scale. Which was first believed to be an outcome of a natural disaster was soon proved to be otherwise. The government led military project 'Project Arrowhead' comes out as a result of creating a host of vicious creatures and the consequent mist. But the reality of such an operation and the means employed to perform them that can lead to a calamity of this proportion is entirely kept hidden from the viewers. The only people knew about this commit suicide before any legitimate interrogation. This elusive pretext of such an outbreak is synonymous to the present world where we sit in midst of a host of information provided online, having absolutely no idea of which one to be true and which one to discard altogether.

\subsection{Shutting Down of Information Agencies}

Just when the crisis reached to its zenith a number of bad actors were seen to offer up junk science. As indicative in Outbreak where the location of the outbreaks though geographically 
unrelated are in every cases a health-care facility, where the victims of such virus are both the patients and their physicians. On similar grounds, much bogus accusations were made about the working system of the hospitals and the ways of tackling the virus. Influential TV and Radio opinions downplayed the importance of masks and that social distancing was nothing but a joke. In an article published in Reuters, they shammed out the misleading information of wearing masks that have been going round by the propagandist media all over the social network when they fact checked with American Lung Association, where pulmonologists David G. Hill, M.D., states on this topic negating the claims of lowering oxygen level when he says, "We wear masks all day long in hospital. The masks are designed to be breathed through and there is no evidence that low oxygen level occurs". At the wake of government elections, these threats to life were regarded as a manipulative technique to influence the people against the prevalent government. Hence those information agencies that raised the courage to present the reality of the deadly virus were untimely shunned. Dr. Ai Fen of Wuhan Central Hospital was concluded to be missing on unknown grounds right after she presented an interview where she flashed out the realities of the virus, and how despite knowing of the virus since December 2019, the government has faltered into taking any actions at all. Instances like these were not rare in the work of art as well where in The Stand we can find the radio jockey of north California is seemed to be executed by the state army as she attempted to bring out the truth about the 'Superflu', or, as they call it 'Captain Trips', when the government only wanted to project it as nothing more than a cold.

On the other hand, in the 2011 Contagion we find the Australian conspiracy theorist and journalist Alan Krumweide acting as a whistle blower to bring out the truth about the 'MEV-1'. He was heel-bound to prove 'MEV-1' to be actually a bio-weapon that was deployed for mass terrorization. Despite providing with information he was in fact arrested for security fraud in order to shut his theory posing a threat to those at power.

\subsection{Manipulation of Data}

It is not difficult to understand that the government statistics are hardly true. The data provided by the government aided researches almost never produce the correct information. The ground reality always seems to be different. It is not a surprise when the same was seen even in the case of a worldwide pandemic. For instance, the report supplemented to the World Health Organization by Malaysia was a total of 533 case counts on $16^{\text {th }}$ of March, 2020. However, a press report published just after three days called this count to be a figure of around 900 . Hijacking of numbers becomes a common practice to manipulate the governmental condition in handling of the cases and providing proper aid to the necessary victims. These are made evident from the twitter movements to question the disproportionate rise in the death in U.S. False information and data moved around the social media and on TV screens as well.

In order to safeguard the blunder at hand the government undertakes different oppressive measures to hide the real picture from the people. The Outbreak follows the same trend when a densely affected locale is asked by the authorities to completely wipe out by bombing upon them. This was a practice to be done totally in oblivious of the knowledge of the residing citizens and with utmost secrecy. Among all the works a cord of similarity that can be perceived is that the evolution of a virus is not self-effacing. A human intervention within the laws of nature gives rise to such disasters. Be it expeditionary warfare in Outbreak, creation of a bio weapon in Contagion and The Stand or, military experimentations in The Mist, all not just receive governmental support, but is safeguarded by them after the mishap as well. Hence it becomes an important point to hide the actual data to minimize the blunder already done. This might be projected as a means to avoid panic among the mass, but a deeper analysis will prove that it is a necessary means to hide the governmental failure in tackling the situation.

\section{Amplified State of the Virus}


Mutation is the very nature of the viruses. Viruses continuously changes as a result of genetic selection. Through mutation or, recombination this change comes about as a menace to the medical field, and the sufferers at large. The order or the specifications of this mutation is neither predictable, nor the effect of such viruses on the people can be calculated exactly. People react differently to this ailment. Almost all the nations fall prey to this rapid change of characteristics. Hence it becomes difficult to cope up with the new problems at hand. The alarm spread even at a greater speed among the media.

\subsection{Mutation of the Virus}

In respect to the prevalent pandemic situation, it can be concluded that the mutation took place at a lot slower pace to that of other outbreaks. Especially keeping into consideration how quickly this spreads; HIV Aids faced a far greater mutation than that of Corona virus. According to a study undertaken by Bette Korber, a computational biologist; it was found that a specific mutation was appearing again and again in the samples extracted from Covid-19 patients. At the $614^{\text {th }}$ amino acid position of spike protein, the amino acid aspartate was continuously replaced by glycine because of a fault in cell copying. As a result of this, a new strain records for new precautionary measures to be adopted by the citizens.

This uncalled change in the nature of the already exponential problem at hand is emphasized in the Outbreak as well. Colonel Sam Daniels right from the beginning of his investigation in Africa was made aware of the fact that the new arisen Motaba Virus is in fact not airborne. A personal protective equipment kit was discouraged at the first place to lower the panic among the patients. But with the spread of the virus which eventually gulped the entire California and the related states; cases started arising of the people who never even came in contact with the affected ones. Upon an investigation about the reality of occurrences it was hence perceived that the mutation of the viruses has indeed began transforming it to become airborne. This brought forward new measures to be undertaken so as to combat the problem at hand. An immediate compulsion of a protective kit came forth as a consequent effect.

It is a known fact that a lower immunity system will always be prone to any kind of attack. Hence a body already beaten down but a virus will be the hub of various other bacterial manifestations. This is understandable when one sees the rise of various other diseases like different strains of fungi, as seen in the recent case study of India. This is to be noted that these growths primarily take place is either an already affected body, or in person in the grip of various other ailments. As a result of this one undergoes the manifestation of multiple diseases all together.

It is unlikely that a novelist like Robin Cook who is also an American physician; and who came into the business of writing in order to lay bare the different medical procedures would not include a process as common as mutation and multiplication of diseases into his writings. In his 1995 novel Contagion we find the protagonist Dr. John Stapelton engaging himself in an investigation upon a series of extremely lethal illness came as a result of a deadly outbreak of a rare kind of influenza. Just as we have perceived, these diseases multiply within the weak, young and the old. The multiplicity of the various strains projected through his fictionalized works successfully brings out the reality of the situation that we are facing today in midst of a true outbreak.

\subsection{Measures of Prevention}

It is hard to compensate the work and the emotional turmoil the frontliners go through. Over the last couple of years through various social media platforms the frontliners came forward to voice out the dire situations mankind has fallen into, and the relentless combating the medical field had to maintain to secure life back to the masses. The situation turned into a war zone, 
where even the medical practitioners had to remain in isolation with limited supplies and responses from the higher authorities as the conditions were equally baffling for all; which nobody knew how to cope up with. With the increasing number of affected patients every single day it is no wonder the hospital beds got dried out sooner than anticipated. The situation took a grimmer turn in developing nations like India where the facilities and population remains inversely proportionate to each other. In an attempt to appease the civilian, bills were passed to create new containment centre. These centres would need fresh supplies and assistance which was again a hard task in midst of horror explosions all over the world. What comes as a shocking coincidence to the avid movie goers is when the exact incident is replicated in Contagion which came out around eight years prior to the outbreak. Yet they beautifully portrayed the complications, massacre and the situational needs of these centres. The continuous heralding of proper sanitation and the necessities of quarantine that rallied the entire day on various platforms to increase the awareness among the citizens was a direct similarity we can draw where the fiction united with the reality.

\subsubsection{The Vaccine Dilemma}

The vaccine might come easier to the stories drawn parallel from, but nevertheless the post vaccine situation cannot be distinguished from reality. With the much awaited dose of relief came a host of conspiracy theories too. Theories about the vaccine causing infertility among women, causing life threatening side effects, especially to the people within the co-morbidity range and other cases of misinformation circled up the people. The early stage of vaccination stimulated much controversy and panic among the citizens. To this Dr. Seema Yasmin, Director of Research and Education Programs at the Stanford Health Communication pointed out, "People are anxious and scared right now... They are looking for a whole picture" (Funke \& Sanders, 2020).

It is understandable that the vaccine that came to people after relentless trials cannot be sufficient in number to vaccinate the entire world population together. This is the exact moment where selection and preference basis steps in. It is only logical that the frontliners deserve to procure them first. It was shocking to see when the candidates liable for a vaccination were selected out of lottery according to their birth dates in Contagion, which is reminiscent of the recruitment of military forces in 1969 to wage the Vietnam War. The shortage of vaccine, the selective process of vaccine, and the long struggle to find the slot to get vaccinated finds too much of an affirmation when Dr. Ellis Cheever, Director for the Centers for Disease Control and Prevention in Atlanta, Georgia is seen to escape some dosages for his own child in midst of vaccine crisis. The black marketing prevalent even today regarding the need of vaccine was indistinguishably portrayed when few men barged into the house of Dr. Cheever breaching the security, in an attempt to illegally take position of the dosages.

The long queue of people outside the government hospitals waiting for their share of dosage only to be informed later that the vaccine is to be available to the first hundred candidates only was a problem portrayed in the said movie replicating the barbaric onslaught the pharmacy outlets went through on declaring about the limitations of the dosage supply.

A worldwide lockdown of unprecedented scale was a notion that existed only in imaginations. Yet, somehow the Earth faced, survived and still combating for a brighter future. But this drastic change of lifestyle in the lives of people across the Nation brought more hurdles than good to say the least. Unemployment became the flag bearer among all the other problems that could make us desperate to return to our normal lives. The economy of even the most developed of nations shook to its very core; enough for the then President of U.S. and the Wall Street executives and economists to question whether the government had gone too far and should lift the restrictions instead.

Covid-19 came as an excuse for the establishment of an autocratic system of rule. The virus came as a pretext to oppression by the authorities and means to consolidate power. In 
North Korea the civil liberties were forfeited in the name of greater good. Xi Jinping, Prime Minister of China demonstrated how the surveillance can be implemented among the citizens by his high-tech authoritarian response and censorship. Even the President of U.S.A. calling the virus as a hoax turned to totalitarian control over the state. The state of a complete lockdown can least be said as a perfect timing for the government of India to safeguard the central authority from the ongoing protests against the policies led down by the central government prior to the outbreak.

\section{References}

AFP. (2020, September 11). North Korea issues shoot-to-kill orders to prevent coronavirus: US. The Hindu. https://www.thehindu.com/news/international/n-korea-issues-shootto-kill-orders-to-prevent-virus-us/article32584747.ece.

BBC News. (2021). Covid-19 pandemic: China 'refused to give data' to WHO team. https://www.bbc.com/news/world-asia-china-56054468.

Burns, J. F. (1994, September 25). Medical Experts Fear Refugees May Spread India Plague. The New York Times. https://www.nytimes.com/1994/09/25/world/medical-experts-fear-refugees-mayspread-india-plague.html.

CBS Sunday Morning. (2021, June 11). Stephen King: During the Pandemic "The real world was kind of scary" [Video]. YouTube. https://youtu.be/SVD4v3d8GpY

Chiu, A. (2020, March 20). Trumphas no qualms about calling coronavirus the 'Chinese Virus.' That's a dangerous attitude, experts say. The Wahington Post. https://www.washingtonpost.com/nation/2020/03/20/coronavirus-trump-chinesevirus/.

Cook, R. (1995). Contagion. New York: Berkley.

Cook, R. (2013). Outbreak. London: Macmillan Bello.

Cook, R. (2019). Pandemic. London: Pan Books.

Darabont, F. (Director). (2007). The Mist [Film]. Darkwoods Productions.

Flint Memorial Library. (2021, February 13). Robin Cook in Conversation with Hank Phillippi Ryan [Video]. YouTube. https://youtu.be/-8SIWSxj87g

Funke, D., Sanders, K. (2020, December 16). Lie of the Year: The Downplay and Denial of the Coronavirus. Kaiser Health News. https://khn.org/news/article/lie-of-the-year-thedownplay-and-denial-of-the-coronavirus.

Garris, M. (Director). (1994). The Stand [Miniseries]. Darkwoods Productions.

King, S. (2012). The Stand. New York: Anchor.

King, S. (2018). The Mist. New York: Scribner.

Petersen, W. (Director). (1995). Outbreak [Film]. Warner Bros. Pictures.

Reuters. (2020). Fact Check: False and misleading information in post listing 'dangers' of face mask. https://www.reuters.com/article/uk-factcheck-masks-listidUSKBN24333G.

Roberts, A. (2020). Pandemics and Politics. Survival: Global Politics and Strategy, 62(5), 740. https://doi.org/10.1080/00396338.2020.1819641.

Sivaramakrishnan, K. (2011). The Return of Epidemics and the Politics of Global-local Health. American Journal of Public Health, 101(6), 1032-41. https://doi.org/10.2105/AJPH.2010.300026.

Soderbergh, S. (Director). (2011). Contagion [Film]. Warner Bros. Pictures.

Thakur, J. (2021, April 18). Bengal: 75 times spike in daily cases after poll announcement. The Hindustan Times. https://www.hindustantimes.com/elections/west-bengal-assembly-election/bengal-75$\underline{\text { times-spike-in-daily-cases-after-poll-announcement-101619555128270.html. }}$ 
Pandemic; A Political Satire: Re-Surfacing the Dysfuctional Government Through the Works of Stephen King and Robin Cook

Volpicelli, G. M. (2020, March 20). Hidden Data Is Revealing the True Scale of the Coronavirus Outbreak. WIRED UK.

https://www.wired.co.uk/article/coronavirus-spread-data.

Xue, J., Chen, J., Chen, C., Hu, R., Zhu, T. (2020). The Hidden Pandemic of Family Violence During COVID-19: Unsupervised Learning of Tweets. Journal of Medical Internet Research, 22(11). https://doi.org/10.2196/24361.

\section{$\underline{\text { Bio-note }}$}

Sanghamitra Ghatak (M.A, B.Ed), have completed her Masters Degree from Aliah University, from the Department of English. She has worked as a guest lecturer in Al-Ameen Memorial Minority College. Currently she is working as an assistant teacher of English under St. Stephen's branch of School.

Email Id: ghataksanghamitra64@gmail.com 